\title{
Subdivision of the dinoflagellate cyst Family Suessiaceae and discussion of its evolution
}

\author{
RAFFAELLA BUCEFALO PALLIANI ${ }^{1}$ \& JAMES B. RIDING ${ }^{2}$ \\ ${ }^{1}$ Department of Earth Sciences, University of Perugia, 06100 Perugia, Italy. \\ ${ }^{2}$ British Geological Survey, Keyworth, Nottingham NG12 5GG, UK.
}

\begin{abstract}
The recent description of Umbriadinium mediterraneense Bucefalo Palliani \& Riding 1997 from the Early Jurassic of central Italy and Greece has provided new information on the phylogeny of the dinoflagellate cyst Family Suessiaceae. On the basis of the morphology of the five suessiacean genera, a subdivision of the family into two new subfamilies is proposed. These are the Late Triassic Suessioideae and the Early Jurassic Umbriadinoideae. The evolution of the Family Suessiaceae is related to the evolution of scleractinian corals, largely on the basis of the similarity of their evolutionary patterns and geographical palaeodistributions. J. Micropalaeontol. 19:(2) 133-137, December 2000.
\end{abstract}

\section{INTRODUCTION}

The recent description of the suessiacean dinoflagellate cyst genus Umbriadinium by Bucefalo Palliani \& Riding (1997) from the early Toarcian (Early Jurassic) of central Italy and Greece in the Tethyan Realm has contributed significantly to our understanding of the phylogeny of the Family Suessiaceae. On morphological grounds, the genera of the Suessiaceae fall into two groups that appear to have distinct stratigraphical ranges. The Norian-Rhaetian (Late Triassic) genera Noricysta, Suessia and Wanneria are placed within the Subfamily Sussioideae, which comprises proximate or proximochorate genera. The subfamily Umbriadinoideae is confined to the Hettangian-early Toarcian (Early Jurassic) and comprises the proximochorate/ chorate genera Beaumontella and Umbriadinium.

\section{SYSTEMATIC PALAEONTOLOGY}

Division Dinoflagellata (Bütschli, 1885) Fensome et al., 1993

Subdivision Dinokaryota Fensome et al., 1993

Class Dinophyceae Pascher 1914

Subclass Gymnodiniphycidae Fensome et al., 1993

Order Suessiales Fensome et al., 1993

Family Suessiaceae Fensome et al., 1993

\section{Subfamily Suessioideae (autonym)}

Type genus Suessia Morbey, 1975 (Late Triassic, Rhaetian) Other genera Noricysta Bujak \& Fisher, 1976 (Late Triassic,

Norian); Wanneria Below, 1987 (Late Triassic, Norian)

Derivation of name. From the genus Suessia Morbey, 1975.

Diagnosis. Acavate or cavate, proximate or proximochorate suessiacean dinoflagellate cysts which exhibit nonparatabular or parasutural ornamentation. Archaeopyle of combination type; operculum simple or compound.

Stratigraphical range. Representatives of the Subfamily Suessioideae nov. are confined to the Carnian to Rhatian (Late Triassic interval).

Remarks: The Subfamily Suessioideae nov. includes Noricysta, the only cavate suessiacean genus. The genera of this subfamily are proximate (Noricysta and Suessia) and proximochorate (Wanneria). Noricysta exhibits nonparatabular ornamentation; the periphragm is typically granular, verrucate or sparsely spinose. Parasutural ornamentation, comprising low crests and spines, is present in Suessia and Wanneria. Below (1987, pl. 6) described and illustrated an outer pellicle in Suessia which has a peridinacean paratabulation pattern. This pellicle was not mentioned in detail in the original description of Suessia, although Morbey $(1975$, p. 38), described the genus as 'pseudocavate' with a periphragm 'closely appressed to or partially detached from (the) endophragm'. The pellicle has not been noted by any other authors. It seems likely that this pellicle is only present in well preserved material as both Morbey (1975) and Below (1987) figured many specimens of Suessia swabiana Morbey, 1975 which are apparently acavate. Furthermore, pellicles have not been observed in any other genera in the family Suessiaceae. All three genera have archaeopyles of combination type. The operculum is simple in Wanneria [operculum formula: $\left(\operatorname{tn}^{4}+\operatorname{tn}^{3}+\mathrm{tn}^{2}\right)_{s}$ ] and is compound in Suessia (operculum formula: $\operatorname{tn}^{3}+\operatorname{tn}^{2}+\operatorname{tn}^{a}$ ). The operculum formula style used here is that of Below (1987). The size of the three genera varies from small to intermediate (of Stover \& Evitt, 1978, p. 5), with a maximum diameter of between $30 \mu \mathrm{m}$ and $55 \mu \mathrm{m}$. A comparison of the two new subfamilies of the family Suessiaceae is presented in Fig. 1.

\section{Subfamily Umbriadinioideae nov}

Type genus Umbriadinium Bucefalo Palliani \& Riding 1997

(Early Jurassic, late Pliensbachian-early Toarcian)

Other genus Beaumontella Below, 1987 (Early Jurassic, Hettangian-Sinemurian).

Derivation of name. From the genus Umbriadinium Bucefalo Palliani \& Riding 1997.

Diagnosis. Acavate, proximochorate and chorate suessiacean dinoflagellate cysts in which intraparatabular ornamentation is present. Archaeopyle type may be apical or combination; operculum compound.

Stratigraphical range. Members of the Subfamily Umbriadinioideae nov. are confined to the Hettangian-early Toarcian (Early Jurassic).

Remarks. The genera belonging to the Subfamily Umbriadinioideae nov. are proximochorate to chorate; proximate cysts are not represented. The ornamentation comprises processes arranged in intraparatabular positions. The archaeopyle is of combination type in Umbriadinium and apical in Beaumontella (Fig. 1). Both genera are characterized by compound opercula. The size is small (Stover \& Evitt, 1978, p. 5); the maximum diameter varies between $15 \mu \mathrm{m}$ and $25 \mu \mathrm{m}$. A comparison of the two new subfamilies in the family Suessiaceae is illustrated in Fig. 1 


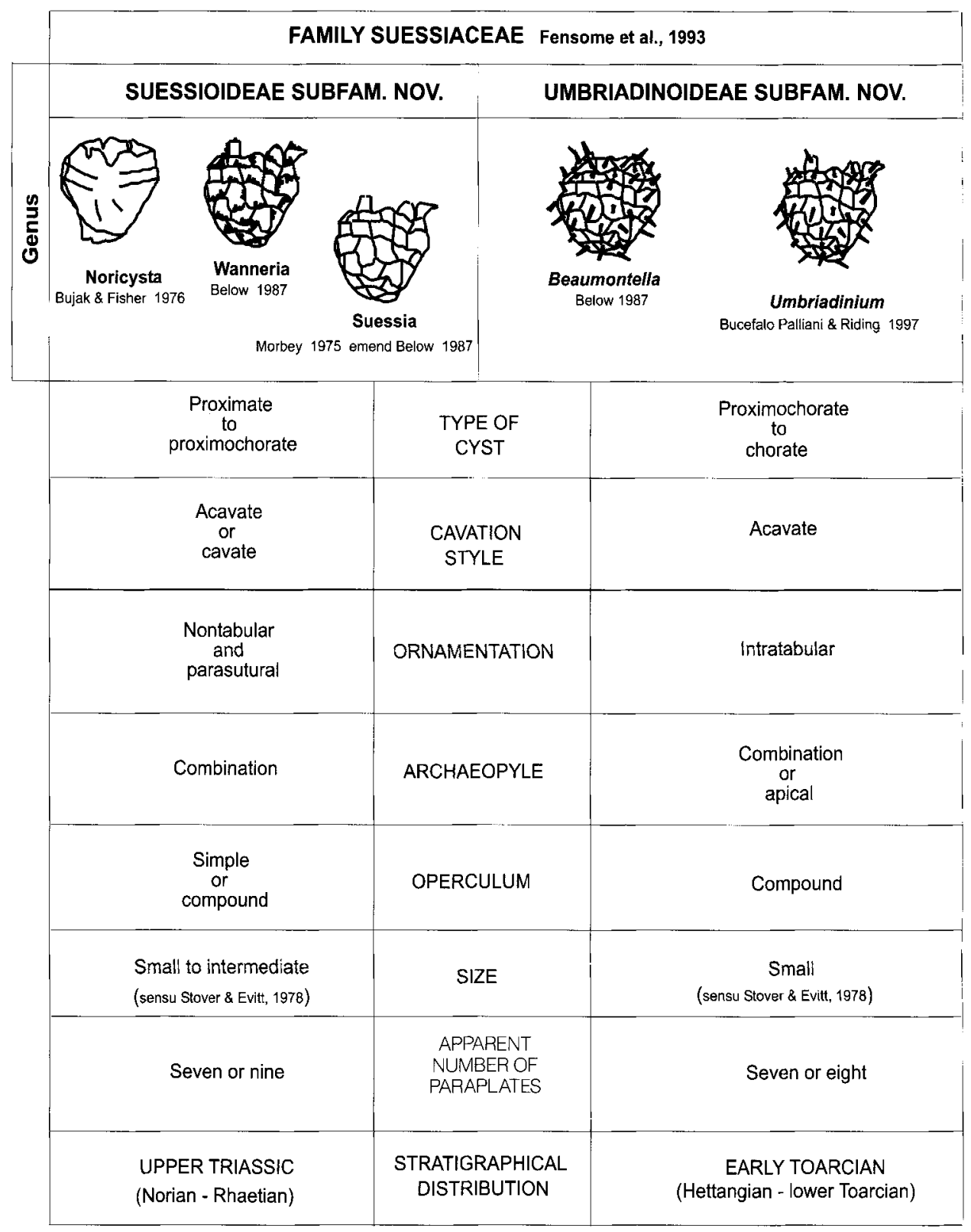

Fig. 1. Schematic representation of the morphological features and stratigraphical distributions of the two subfamilies of the Family Suessiaceae.

\section{THE EVOLUTION OF THE FAMILY SUESSIACEAE}

Significant morphological changes, which facilitate the subdivision of the dinoflagellate cyst Family Suessiaceae into two subfamilies, occurred at the Triassic-Jurassic transition. This boundary coincides with a mass extinction, that is clearly marked in the marine realm by a dramatic turnover of ammonites, the final disappearance of conodonts and substantial biotic changes to other fossil groups (Hallam, 1990, 1996). The dominant Triassic nannolith lineages became extinct, leaving only one coccolith species which survived into the Jurassic (Bown, 1992). Hallam (1990) linked this extinction event to a sea-level change in the form of a regressivetransgressive couplet associated with the inception of tensional tectonic and volcanicity in the central part of Pangea. Dinoflagellate cysts underwent a significant extinction event at the Triassic-Jurassic boundary, $c$. $13 \mathrm{Ma}$ after their first unequivocal occurrence.

\section{Morphological trends within the Suessiaceae}

During the Late Triassic, the Order Suessiales was represented by the Subfamily Suessioideae (Family Suessiaceae); i.e. the genera Noricysta, Suessia and Wanneria. The highest species diversity is in Noricysta (Noricysta fimbriata Bujak \& Fisher 1976; Noricysta pannucea Bujak \& Fisher, 1976; and Noricysta varivallata Bujak \& Fisher, 1976) (see Bujak \& Fisher, 1976) and Wanneria (Wanneria listeri (Stover \& Helby, 1987) Below, 1987; 
at the familial and generic levels. A major generic turnover of corals occurred during the Toarcian (Stanley, 1988). According to Beauvais (1986), all Triassic genera had become extinct by this time. The Toarcian turnover phase coincided with a profound reorganization of reef ecosystems which continued into the Middle Jurassic; it comprised a major adaptive radiation unparalleled among reef corals (Stanley, 1988). This event signalled a renewed differentation of corals between zooxanthellate and azooxanthellate types (Stanley, 1981; Krasimov, 1984).

The turnover in the Family Suessiaceae at the TriassicJurassic transition (Fig. 2) corresponded with a gradual taxonomic modification of corals. Both fossil groups lost their Triassic morphological characteristics at the family level and recorded a largely complete turnover. The major change of coral faunas at the generic level in the Toarcian seems to correspond with a profound change within suessiacean dinoflagellate cysts, responsible for their disappearance from the fossil record. A possible hypothesis is that, at this time, the suessiacean dinofiagellates lost the capacity to produce fossilizable resting cysts.

During the Carboniferous to Jurassic, the main global reef production shifted from the Southern Hemisphere to the Northern Hemisphere (Flügel, 1994; Flügel \& Kiessling, 1996). Reef distribution was restricted to a latitudinal zone from $30^{\circ} \mathrm{N}$ to $30^{\circ} \mathrm{S}$ during the Middle Triassic and, during the Jurassic, bioherms seem to have been concentrated near $30^{\circ} \mathrm{N}$, especially in Europe and at the eastern margin of North America (Flügel, 1994; Flügel \& Kiessling, 1996). A similar trend is discernible in the distribution of suessiacean dinoflagellate cysts. They show a worldwide geographical distribution during the Late Triassic to the Triassic-Jurassic transition and have been reported from Aretic Canada, Australia, Austria and England (Morbey, 1975, 1978; Bujak \& Fisher, 1976; Schuurman, 1979; Dörhöfer \& Davies, 1980; Davies, 1983; Helby et al., 1987; Riding \& Thomas, 1992). During the Early Jurassic, however, suessiacean dinoflagellate cysts are confined to low-intermediate palaeolatitudes in the Northern Hemisphere (England, Denmark, Greece, Hungary, Italy and Portugal) (Riding \& Thomas, 1992; Bucefalo Palliani, 1996; Poulsen, 1996; Bucefalo Palliani \& Riding, 1997). Representatives of the Family Suessiaceae are not present in the Early Jurassic of the Southern Hemisphere (Helby et al., 1987) or in high latitudes of the Northern Hemisphere, for example Arctic Canada, Greenland, the North Sea and Spitsbergen (Dörhöfer \& Davies, 1980; Davies, 1983).

\section{Acknowledgements}

This research was supported by a Training and Mobility of Researchers (TMR) European Commission research grant (contract number ERBFMBICT960661) and by the research funds of Prof Simonetta Cirilli (University of Perugia). The authors wish to thank Drs Robert A. Fensome (Geological Survey of Canada) and Ron Woollam (Millennia Stratigraphic Consultants) for reviewing the manuscript. J. B. Riding publishes with the permission of the Director, British Geological Survey (NERC).

\section{Manuscript received December 1999 Manuscript accepted August 2000}

\section{REFERENCES}

Beauvais, L. 1984. Evolution and diversification of Jurassic scleractinia Palaeontographica Americana, 54: 219-224.

Beauvais, L. 1986. Monographie des Madrèporaires du Jurassique infèrieur du Maroc. Palaeontographica Americana, 194: 1-68.

Below, R. 1987. Evolution und Systematik von Dinoflagellaten-Zysten aus der Ordnung Peridiniales. I. Allgemeine Grundlagen und Subfamilie Rhactogonyaulacoidae (Familie Peridiniaceac). Palseontographica, Abteilung B, 205: 1-178.

Bown, P. R. 1992. Late Triassic-Early Jurassic Calcareous Nannofossils of the Queen Charlotte Islands, British Columbia. Journal of Micropalaeontology, 11: 177-188.

Bucefalo Palliani, R. 1996. Facies organiche nel Giurassico inferiore del dominio Tetideo: sedimentologia organica e biostratigrafia a cisti di dinoflagellati. PhD thesis, University of Perugia, Italy, $250 \mathrm{pp}$.

Bucefalo Palliani, R. \& Riding, J. B. 1997. Umbriadinitim mediterraneense gen. et sp. nov, and Valvaeodinium hirsutum sp. nov:: two dinoflagellate cysts from the Lower Jurassic of the Tethyan Realm. Palynology, 21: 197-206.

Bujak, J. P. \& Fisher, M. J. 1976. Dinoflagellate cysts from the Upper Triassic of arctic Canada. Micropaleontology, 22: 44-70.

Davies, E. H. 1983. The dinoflagellate Oppel-zonation of the JurassicLower Cretaceous sequence in the Sverdrup Basin, Arctic Canada. Geological Survey of Canada Bulletin, 359, 59pp.

Dörhöfer, G. \& Davies, E. H. 1980. Evolution of archeopyle and tabulation in Rhaetogonyaulacinean dinoflagellate cysts. Royal Ontario Museam, Life Sciences Miscellaneous Publications, $91 \mathrm{pp}$.

Fensome R. A., Taylor, F. J. R., Norris, G., Sarjeant, W. A. S., Wharton, D. I. \& Williams, G. L. 1993. A classification of living and fossil dinoflagellates. Micropaleontology, Special Publication 7, 351 pp.

Fisher, M. J. \& Van Helden, B. G. T. 1979. Some observations on the fossil dinocyst genus Rhaetogonyaulax Sarjeant, 1966. Palynology, 3 : 265-276.

Flügel, E. 1994. Pangean shelf carbonates: controls and paleoclimatic significance of Permian and Triassic reefs. Geological Society of America, Special Paper 288, 247-266.

Flügel, E. \& Kiesseling, W. 1996. Paleoreef maps - Phanerozoic reef patterns: a progressive report. Abstracts volume: 'Carbonates and global change: an interdisciplinary approach' SEPM/IAS Conference, June 1996 Switzerland, 54-55.

Hallam, A. 1990. The end-Triassic mass extinction event. Geological Society of America, Special Paper 247: 577-583.

Hallam, A. 1996. Recovery of the marine fauna in Europe after the endTriassic and early Toarcian mass extinctions. In Hart, M.B. (Ed.), Biotic Recovery from Mass Extinction Events, 231-236. Geological Society, London, Special Publication 102.

Harland, R., Morbey, S. J. \& Sarjeant, W. A. S. 1975. A revision of the Triassic to lowest Jurassic dinoflagellate Rhaetogonyaulax. Palaeontology, 18: 847-864.

Helby, R., Morgan, R. \& Partridge, A. D. 1987. A palynological zonation of the Australian Mesozoic. Studies in Australian Mesozoic Palynology. Association of Australasian Paleontologists Memoir, 4: $1-94$.

Krasimov, E. V. 1984. Evolutionary trends of scleractinians and coral communities in post-Paleozoic time. Palaeontographica Americana, 54: 225 .

Loeblich III, A. R. \& Sherley, J. L. 1979. Observations on the theca of the motile phase of free-living and symbiotic isolates of Zooxanthella microadriatica (Freudenthal) comb. nov. Journal of the Marine Biological Association of the United Kingdom, 59: 195-205.

Morbey, S. J. 1975. The paiynostratigraphy of the Rhaetian stage, Upper Triassic in the Kendelbachgraben, Austria. Palaeontographica, Abteilung B, 152: 1-75.

Morbey, S. J. 1978. Late Triassic and Early Jurassic subsurface palynostratigraphy in northwestern Europe. Palinologia número extraordinario, 1: $355-365$.

Newell, N. D. 1971. An outline history of tropical organic reefs. American Museum Novitates 2465: 1-37.

Poulsen, N. E. 1996. Dinoflagellate cysts from marine Jurassic deposits of Denmark and Poland. American Association of Stratigraphic Palynologists Foundation Contribution Series, 31, 227pp.

Riding, J. B. \& Thomas, J. E. 1992. Dinoflagellate cysts of the Jurassic 
Suessiaceae dinoflagellate cysts: taxonomy and evolution

System. In Powell, A. J. (Ed.), A stratigraphic index of dinoflagellate cysts 7-97. British Micropalaeontological Society Publications Series, Chapman \& Hall, London.

Rowan, R. \& Powers, D. A. 1991. A molecular genetic classification of zooxanthellae and the evolution of animal-algal symbiosis. Science, 251: $1348-1351$.

Schuurman, W. M. L. 1979. Aspects of Late Triassic palynology. 3. Palynology of latest Triassic and earliest Jurassic deposits of the Northern Limestone Alps in Austria and southern Germany, with special reference to a palynological characterisation of the Rhaetian Stage in Europe. Review of Paleobotany and Palynology, 27: 53-75.

Stanley, G. D. 1981. Early history of scleractinian corals and its geological consequences. Geology, 9: 507-511.
Stanley, G. D. 1988. The history of Early Mesozoic reef communities: a three-step process. Palaios, 3: 170-183.

Stanley, G. D. 1992. Tropical reef ecosystem. In Nierenberg, W.A. (Ed.), Encyclopedia of Earth System Science, 4, 375-388. Academic Press, .

Stanley, G. D. \& Swart, P. K. 1995. Evolution of the coral-zooxanthelle symbiosis during the Triassic: a geochemical approach. Paleobiology, 21: $179-199$

Stover, L. E. \& Evitt, W. R. 1978. Analyses of pre-Pleistocene organicwalled dinoflagellates. Stanford University Publications, Geological Sciences, 15, 300pp.

Talent, J. A. 1988. Organic reef-building episodes of extinction and symbiosis? Senkenhergiana Lethaea, 69: 315-368. 